\title{
FES wt Allele
}

National Cancer Institute

\section{Source}

National Cancer Institute. FES wt Allele. NCI Thesaurus. Code C51076.

Human FES wild-type allele is located in the vicinity of $15 q 26.1$ and is approximately $11 \mathrm{~kb}$ in length. This allele, which encodes proto-oncogene tyrosine-protein kinase Fes/Fps protein, plays a role in signal transduction. The FES gene is translocated in acute promyelocytic leukemia. 